\title{
New altitudinal record for Brachycephalus actaeus Monteiro, Condez, Garcia, Comitti, Amaral \& Haddad, 2018 (Anura, Brachycephalidae), with comments on its habitats of occurrence
}

\author{
Marcos Ricardo Bornschein ${ }^{1,2}$, Luiz Fernando Ribeiro ${ }^{2,3}$, Larissa Teixeira1, Marcio Roberto Pie ${ }^{2,4}$ \\ 1 Instituto de Biociências, Universidade Estadual Paulista, Praça Infante Dom Henrique s/no, São Vicente, SP, CEP 11330-900, Brazil. 2 Mater \\ Natura - Instituto de Estudos Ambientais, Rua Lamenha Lins 1080, Curitiba, PR, CEP 80250-020, Brazil. 3 Escola de Ciências da Vida, Pontifícia \\ Universidade Católica do Paraná, Rua Imaculada Conceição 1155, Curitiba, Curitiba, PR, CEP 80215-901, Brazil. 4 Departamento de Zoologia, \\ Universidade Federal do Paraná, Caixa Postal 19020, Curitiba, PR, CEP 81531-980, Brazil. \\ Corresponding author: Marcos Ricardo Bornschein, bornschein.marcao@gmail.com
}

\begin{abstract}
Brachycephalus actaeus Monteiro, Condez, Garcia, Comitti, Amaral \& Haddad, 2018 is a recently described member of the B. pernix species group from northeastern Santa Catarina, southern Brazil, where it has been recorded from six localities at altitudes of 20-220 m. At the time of its description, this species was believed to be associated with lowlands, a unique trait for members of the B. pernix group. Here, we extend altitudinal distribution of B. actaeus to $530 \mathrm{~m}$ elevation and determine that the species occupies only montane forests.
\end{abstract}

Keywords

Brachycephalus pernix group, Floresta Ombrófila Densa das Terras Baixas, lowlands, montane forest, sandy soil.

Academic editor: Marcelo Gehara | Received 22 August 2019 | Accepted 12 November 2019 | Published 29 November 2019

Citation: Bornschein MR, Ribeiro LF, Teixeira L, Pie MR (2019) New altitudinal record for Brachycephalus actaeus Monteiro, Condez, Garcia, Comitti, Amaral \& Haddad, 2018 (Anura, Brachycephalidae), with comments on its habitats of occurrence. Check List 15 (6): 1031-1036. https:// doi.org/10.15560/15.6.1031

\section{Introduction}

Brachycephalus Fitzinger, 1826 includes 36 species of small, diurnal anurans endemic to the Atlantic Forest biome of Brazil. Interestingly, 30 of those species were described in the last 20 years. These anurans do not exceed $2.5 \mathrm{~cm}$ in body length (snout-vent) and have reduced number and size of digits (e.g. Yeh 2007). Some species are brightly colored with neurotoxins in their skin (Schwartz et al. 2007). In general, Brachycephalus is characterized by small geographical distributions, with several species being micro-endemic to a single or a few adjacent mountaintops of the Atlantic Forest (Bornschein et al. 2016a).
Environmental niche modeling grouped Brachycephalus into three species clusters based on their climatic niches (Pie et al. 2013). Those clusters were then shown to match closely three phenetic groups of species (Ribeiro et al. 2015), which respond differently to altitude (Bornschein et al. 2016a). For instance, species from the B. ephippium and B. pernix groups (Ribeiro et al. 2015) are closely associated with higher altitudes (Bornschein et al. 2016a). Although there are some populations of these groups at relatively lower altitudes, they tend to be considered as montane groups because they only occur under specific microclimate conditions typical of montane habitats (Bornschein et al. 2016a). On the 
other hand, the $B$. didactylus group (Ribeiro et al. 2015) includes species that are variable in altitudinal distribution, occurring from sea level up to $1,110 \mathrm{~m}$ above sea level (a.s.1.) (Bornschein et al. 2016a).

High-altitude dependence of the montane groups of Brachycephalus has been associated with speciation by isolation (Bornschein et al. 2016a; Firkowski et al. 2016). An increasing warmer and wetter climate, particularly over the past $5 \mathrm{My}$, led to a shift in the distribution of the cold-adapted forest types to higher altitudes, favoring the isolation and speciation of montane Brachycephalus populations in sky islands (Bornschein et al. 2016a; Firkowski et al. 2016; Pie et al. 2018a). Recently, an additional species of the montane $B$. pernix group from northern Santa Catarina, B. actaeus Monteiro, Condez, Garcia, Comitti, Amaral \& Haddad, 2018, has been described and associated with lowlands (Monteiro et al. 2018). In this work, we present new altitudinal records for $B$. actaeus and discuss its occurrence habitats.

\section{Methods}

We actively searched for individuals of B. actaeus, guided by their calls. These searches were made during the day, given that Brachycephalus are usually the only amphibians that call continuously during this period. Upon detecting their calls, we approached them to make recordings and to try to find specimens by removing the leaf litter under which they shelter. We collected specimens, which were deposited in the Museu de História Natural Capão da Imbuia, Curitiba, Paraná. We classified the habitats of collections according to the Brazilian Vegetation Classification System (Veloso et al. 1991). Prior to the description of B. actaeus, we visited localities cited in Monteiro et al. (2018) and classified the habitats according the classification of Veloso et al. (1991).

The datum used for recording geographical coordinates was WGS84. Collections were made under a permit issued by ICMBio/SISBIO (\#55918-1).

\section{Results}

New records. Brazil: Santa Catarina, municipality of Itapoá: Serra da Tiririca $\left(26^{\circ} 07^{\prime} 42^{\prime \prime} \mathrm{S}, 048^{\circ} 44^{\prime} 32^{\prime \prime} \mathrm{W}\right.$; 170-530 m a.s.l.; Fig. 1), 11 January 2017, coll. by Mar$\cos$ R. Bornschein, Marcio R. Pie, Luiz F. Ribeiro, André E. Confetti, and Mário J. Nadaline (10 unsexed specimens; MHNCI 10832, 10833, 10834, 11024, 11025, 11026, 11027, 11028, 11029, 11030; Fig. 2).

We recorded Brachycephalus actaeus in a montane dense ombrophylous forest (Floresta Ombrófila Densa Montana) at Serra da Tiririca (Table 1). We also recorded the species in a submontane dense ombrophylous forest (Floresta Ombrófila Densa Submontana) at Braço do Norte $\left(26^{\circ} 07^{\prime} 30^{\prime \prime} \mathrm{S}, 048^{\circ} 43^{\prime} 47^{\prime \prime} \mathrm{W}\right.$; 210-220 m a.s.1.), municipality of Itapoá, Santa Catarina, on 11 January 2017, and in a submontane dense ombrophylous forest at Serra da Palha $\left(26^{\circ} 17^{\prime} 50^{\prime \prime} \mathrm{S}, 048^{\circ} 40^{\prime} 27^{\prime \prime} \mathrm{W}\right.$; 60-90 $\mathrm{m}$ a.s.l.; Table 1), Laranjeiras, Ilha de São Francisco, municipality of São Francisco do Sul, Santa Catarina, on 18 February 2017, where we were not successful in collecting specimens, despite hearing their calls.

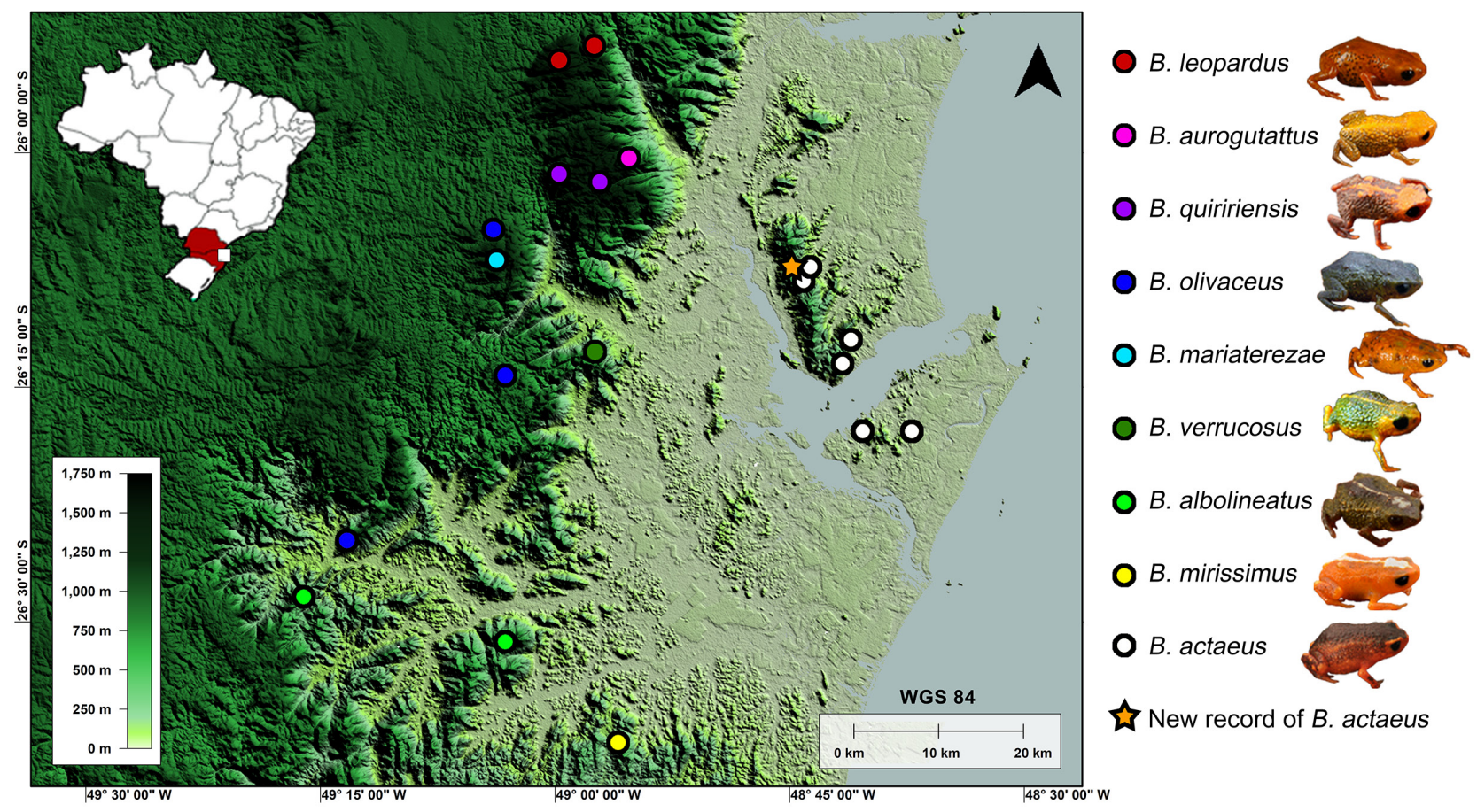

Figure 1. Geographic distribution of Brachycephalus actaeus, highlighting the new record at $530 \mathrm{~m}$ above sea level (orange star) and previous records (black and white dots) of the literature (up to $220 \mathrm{~m}$ above sea level; Monteiro et al. 2018), Santa Catarina, southern Brazil. All Brachycephalus records are also presented within a $50 \mathrm{~km}$ radius of records of B. actaeus (based on Bornschein et al. 2016a; Pie et al. 2018b; Teixeira et al. 2018). 
Table 1. Altitudinal (m a.s.l.; rounded to the nearest five) distribution range and habitat of occurrence of Brachycephalus spp. In the source column, we only cited the sources that update Bornschein et al. (2016a).

\begin{tabular}{|c|c|c|c|c|c|c|c|c|c|c|c|c|}
\hline \multirow{3}{*}{ Species } & \multirow{3}{*}{$\begin{array}{l}\text { Altitudinal } \\
\text { range }\end{array}$} & \multirow{3}{*}{$\begin{array}{l}\text { Altitudinal } \\
\text { amplitude }\end{array}$} & \multirow{3}{*}{ Source } & \multicolumn{9}{|c|}{ Habitat ${ }^{1}$} \\
\hline & & & & \multicolumn{7}{|c|}{ Arboreal vegetation ${ }^{2}$} & \multicolumn{2}{|c|}{ Grassland $^{3}$} \\
\hline & & & & DAM & DM & DSM & DTB & OM & ES & Sec & RV & $\mathbf{E}$ \\
\hline B. didactylus group & $0-1,205$ & 1,205 & & $x$ & $x$ & $\mathrm{X}$ & $x$ & $x$ & & $x$ & & \\
\hline B. didactylus & $35-1,110$ & 1,075 & & & & & & & & & & \\
\hline B. hermogenesi & $0-1,090$ & 1,090 & This study & & $x$ & $x$ & $x$ & & & $\mathrm{x}$ & & \\
\hline B.pulex & $800-930$ & 130 & & & $x$ & & & & & & & \\
\hline B. sulfuratus & $40-1,205$ & 1,165 & This study & $x$ & $x$ & $\mathrm{X}$ & & $x$ & & $\mathrm{X}$ & & \\
\hline B. ephippium group & $200-1,900$ & 1,700 & & & $x$ & & & & $x$ & $x$ & & \\
\hline B. alipioi & $1,070-1,100$ & 30 & & & $\mathrm{x}$ & & & & & & & \\
\hline B. bufonoides & $?$ & $?$ & & & & & & & & & & \\
\hline B. crispus & $800-1,190$ & 390 & This study & & $\mathrm{X}$ & & & & & & & \\
\hline B. darkside & $1,265-1,500$ & 235 & Guimarães et al. 2017 & & & & & & $x$ & & & \\
\hline B. ephippium & $200-1,250$ & 1,050 & & & & & & & & & & \\
\hline B. garbeanus & $1,130-1,900$ & 770 & & & & & & & & & & \\
\hline B.guarani & $500-900$ & 400 & & & & & & & & & & \\
\hline B. margaritatus & $600-980$ & 380 & & & & & & & & & & \\
\hline B. nodoterga & $700-900$ & 200 & This study & & $\mathrm{x}$ & & & & & & & \\
\hline B. pitanga & $900-1,140$ & 240 & & & $x$ & & & & & $x$ & & \\
\hline B. toby & $750-1,060$ & 310 & This study & & $x$ & & & & & & & \\
\hline B. vertebralis & $760-1,110$ & 350 & This study & & $x$ & & & & & & & \\
\hline B. pernix group & $20-1,770$ & 1,760 & & $x$ & $x$ & $x$ & & & & $x$ & $x$ & $\mathrm{x}$ \\
\hline B. actaeus & $20-530$ & 510 & $\begin{array}{l}\text { This study, Monteiro et } \\
\text { al. } 2018\end{array}$ & & $x$ & $x$ & & & & & & \\
\hline B. albolineatus & $500-835$ & 335 & $\begin{array}{l}\text { Bornschein et al. 2016b, } \\
\text { Teixeira et al. } 2018\end{array}$ & & $x$ & & & & & & & \\
\hline B. auroguttatus & $1,070-1,100$ & 30 & & $\mathrm{X}$ & & & & & & & & \\
\hline B. boticario & 685-795 & 110 & This study & & $x$ & & & & & & & \\
\hline B. brunneus & $1,095-1,770$ & 675 & This study & $x$ & $x$ & & & & & $\mathrm{x}$ & & \\
\hline B. coloratus & $1,145-1,230$ & 85 & Ribeiro et al. 2017 & $x$ & $\mathrm{x}$ & & & & & & & \\
\hline B. curupira & $1,095-1,320$ & 225 & $\begin{array}{l}\text { This study, Ribeiro et al. } \\
2017 \text {, Pie et al. 2018a }\end{array}$ & $\mathrm{X}$ & $x$ & & & & & $x$ & & \\
\hline B. ferruginus & $965-1,470$ & 505 & & $\mathrm{x}$ & & & & & & & & \\
\hline B. fuscolineatus & $525-790$ & 265 & Bornschein et al. 2019 & & $x$ & & & & & & & \\
\hline B. izecksohni & $980-1,340$ & 360 & & $x$ & $x$ & & & & & & $x$ & \\
\hline B. leopardus & $1,340-1,645$ & 305 & This study & $x$ & & & & & & & & $x$ \\
\hline B. mariaeterezae & $1,265-1,270$ & 5 & & $x$ & & & & & & & & \\
\hline B. mirissimus & $470-540$ & 70 & Pie et al. 2018b & & $\mathrm{X}$ & & & & & & & \\
\hline B. olivaceus & $650-985$ & 335 & This study & & $x$ & & & & & & & \\
\hline B.pernix & $1,135-1,405$ & 270 & & $x$ & & & & & & & & \\
\hline B. pombali & $845-1,300$ & 455 & & $\mathrm{X}$ & $x$ & & & & & & & \\
\hline B. quiririensis & $1,240-1,380$ & 140 & & $x$ & & & & & & & & \\
\hline B. tridactylus & 805-910 & 105 & & & $x$ & & & & & & & \\
\hline$B$. verrucosus & $455-945$ & 490 & & & $x$ & & & & & & & \\
\hline
\end{tabular}

Incertae sedis

B. atelopoide

${ }^{1}$ Habitat classified according Veloso et al. (1991) by personal observation of the authors of the habitat of the species or if classified in the literature (Guimarães et al. 2017).

${ }^{2}$ Arboreal vegetation: DAM = Floresta Ombrófila Densa Altomontana (highland dense ombrophilous forest); DM = Floresta Ombrófila Densa Montana (montane dense ombrophylous forest); DSM = Floresta Ombrófila Densa Submontana (submontane dense ombrophilous forest); DTB = Floresta Ombrófila Densa das Terras Baixas (lowland dense ombrophylous forest); OM = Floresta Ombrófila Mista Montana (mixed montane ombrophylous forest); ES = Floresta Estacional Semidecidual Montana (montane semideciduous seasonal forest); Sec = secondary vegetation not yet regenerated into a forest stage.

${ }^{3}$ Grassland: RV = Refúgio Vegetacional (or campos de altitude); E = Estepe Gramíneo Lenhosa (or campos de altitude).

Identification. Our specimens collected at Serra da Tiririca closely resemble the paratype of B. actaeus represented in figure 6A of Monteiro et al. (2018). The specimens unambiguously match the $B$. pernix group by the presence of a bufoniform body shape and the linea masculina (Pie et al. 2018b). Within this group, B. actaeus can be easily distinguished from $B$. ferruginus Alves, Ribeiro, Haddad \& Reis, 2006, B. izecksohni Ribeiro,
Alves, Haddad \& Reis, 2005, B. leopardus Ribeiro, Firkowski \& Pie, 2015, B. mariaeterezae Bornschein, Morato, Firkowski, Ribeiro and Pie, 2015, B. mirissimus Pie, Ribeiro, Confetti, Nadaline \& Bornschein, 2018, B. pombali Alves, Ribeiro, Haddad \& Reis, 2006, and B. tridactylus Garey, Lima, Hartmann \& Haddad, 2012 in having dorsal parts predominantly brownish instead of entirely yellow or orange dorsal parts, at 

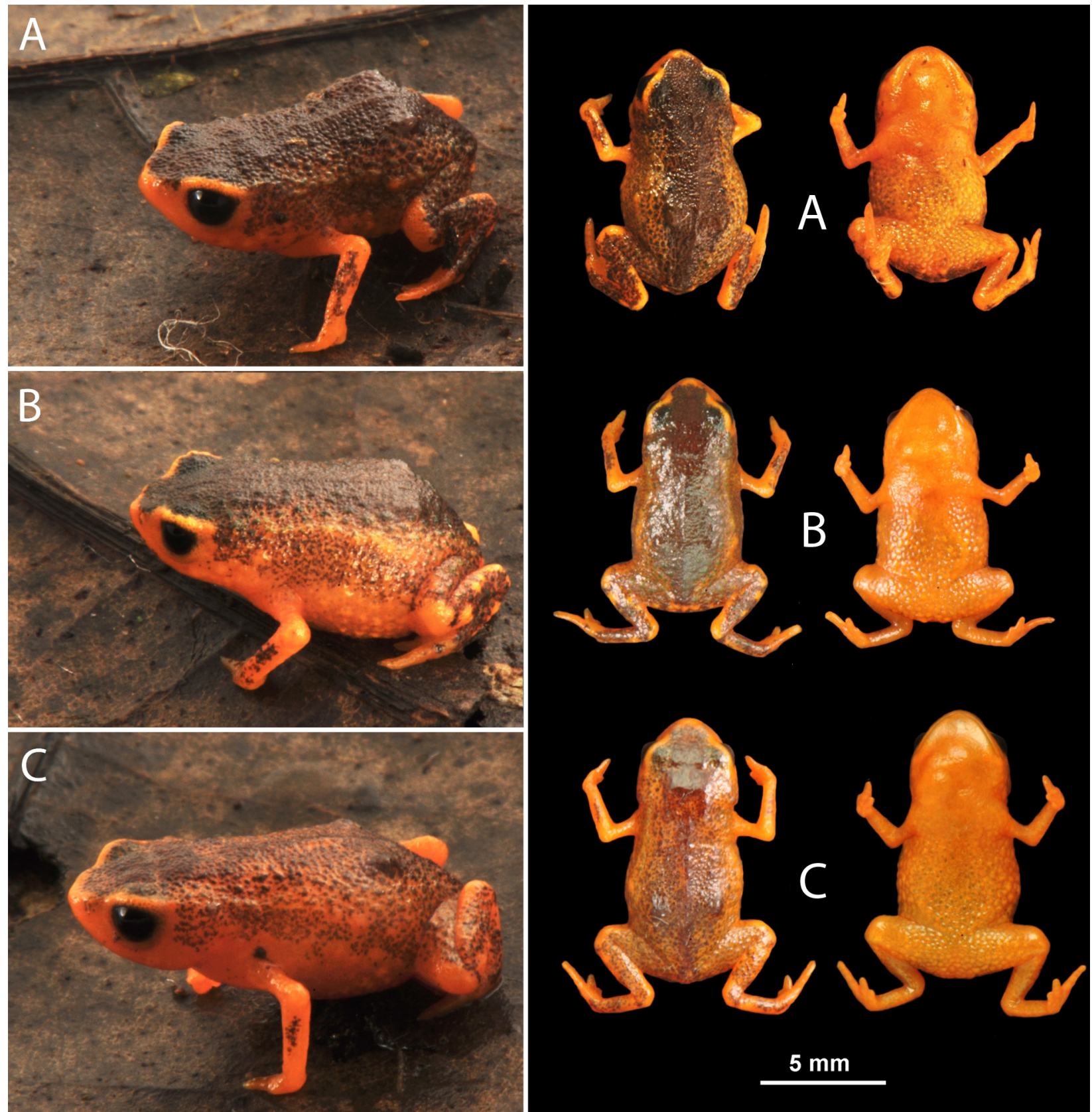

Figure 2. Representative variation in coloration of Brachycephalus actaeus from Serra da Tiririca, municipality of Itapoá, Santa Catarina, southern Brazil. All adults are alive and shown in lateral, dorsal, and ventral view. A. MHNCl 10833. B. MHNCl 10832. C. MHNCl 10834. Abbreviation: $\mathrm{MHNCl}=$ Museu de História Natural Capão da Imbuia, Curitiba, Paraná.

least with a narrow blue (B. mariaeterezae), white stripe (B. mirissimus), or orange dots (B. ferruginus). Brachycephalus auroguttatus Ribeiro, Firkowski, Bornschein \& Pie, 2015, B. boticario Pie, Bornschein, Firkowski, Belmonte-Lopes \& Ribeiro, 2015, B. pernix Pombal, Wistuba \& Bornschein, 1998, B. quiririensis Pie \& Ribeiro, 2015, and B. verrucosus Ribeiro, Firkowski, Bornschein $\&$ Pie, 2015 have a yellow stripe on the middle of their dorsum instead of the entirely brownish dorsum of $B$. actaeus. Brachycephalus fuscolineatus Pie, Bornschein, Firkowski, Belmonte-Lopes \& Ribeiro, 2015 has a brown stripe on the middle of the dorsum and a vivid orange elsewhere, whereas $B$. actaeus has a more extensive brown area in the middle of the dorsum, surrounded by dark orange washed with brown. Brachycephalus albolineatus Bornschein, Ribeiro, Blackburn, Stanley \& Pie, 2016 and B. olivaceus Bornschein, Morato, Firkowski, Ribeiro \& Pie, 2015 have the dorsal and lateral parts of the body predominantly green instead of brown dorsal parts with orange washed brown lateral parts of the body of B. actaeus. Brachycephalus brunneus Ribeiro, Alves, Haddad \& Reis, 2005 and B. curupira Ribeiro, Blackburn, Stanley, Pie \& Bornschein, 2017 have ventral parts predominantly brown instead of predominantly orange. Finally, B. coloratus Ribeiro, Blackburn, Stanley, Pie \& Bornschein, 2017 has a reddish dorsum and green lateral parts of the body, clearly contrasting with a brown dorsum and orange washed brown lateral parts of B. actaeus. 
In having a rough dorsum, $B$. actaeus is also distinct from 10 other species of the $B$. pernix group, which present a smooth dorsum, namely: B. albolineatus, B. brunneus, B. coloratus, B. curupira, B. ferruginus, B. izecksohni, B. leopardus, B. pernix, B. pombali, and B. tridactylus.

These colorations and skin texture of the dorsum were assessed from material examined by us over the past years. Lists of vouchers can be followed in recent publications (Ribeiro et al. 2015, 2017; Bornschein et al. 2016b, Pie et al. 2018b; Teixeira et al. 2018). These sources of species descriptions were also used by Monteiro et al. (2018) in the diagnosis that they proposed of B. actaeus. Thus, the comparisons that these authors and we provide, based on the two sources of morphological characters that we use, are totally congruent.

\section{Discussion}

We recorded Brachycephalus actaeus at three localities, two of which (Braço do Norte and Serra da Palha) were already known (Monteiro et al. 2018). For the new locality (Serra da Tiririca) we report an extension of the altitudinal distribution of B. actaeus from $220 \mathrm{~m}$ a.s.l. (Monteiro et al. 2018) to $530 \mathrm{~m}$ a.s.l. This species now has an altitudinal range of distribution of $510 \mathrm{~m}$, a narrower altitudinal distribution than recorded for three species of the $B$. didactylus group ( $>1,000 \mathrm{~m}$; Table 1), two species of the B. ephippium group (Table 1), and one species of the B. pernix group (B. brunneus, with $695 \mathrm{~m}$ of altitudinal distribution; Table 1). This altitudinal distribution of $510 \mathrm{~m}$ is similar to that recorded for B. ferruginus $(505 \mathrm{~m})$, B. verrucosus $(490 \mathrm{~m})$, and $B$. pombali (455 m;), all within the $B$. pernix species group, and is wider than those recorded from remaining Brachycephalus species (Table 1).

Monteiro et al. (2018) associated B. actaeus with "lowlands" (no terminological basis was offered). This association may have been based on the lower altitude (20 m) that Monteiro et al. recorded the species at Serra da Palha. According to Veloso et al. (1991), the forest type that occurs in the lowlands is lowland dense ombrophylous forest (Floresta Ombrófila Densa das Terras Baixas). This is the forest type of Pleistocene plains and typically grows over sandy soils between 5-30 $\mathrm{m}$ a.s.1. in meridional latitudes $\left(24-32^{\circ} \mathrm{S}\right.$; Veloso et al. 1991). Although it is possible that lowlands forests occur at $20 \mathrm{~m}$ a.s.l. in the latitude of occurrence of B. actaeus (Veloso et al. 1991), that is not the case at Serra da Palha, given that at $15 \mathrm{~m}$ a.s.l. and above we found only montane forests (submontane dense ombrophilous forest; MRB pers. obs.) at this locality.

Within its altitudinal range, B. actaeus occurs in two types of montane forest (montane dense ombrophylous forest and submontane dense ombrophylous forest; Table 1). Five other species of the B. pernix group also occur in two types of montane forest (highland dense ombrophylous forest and montane dense ombrophylous forest;
Table 1). However, B. actaeus is the only species of this group that occurs in the submontane dense ombrophylous forest. In the lowland dense ombrophylous forest, there are records of $B$. hermogenesi (Giaretta \& Sawaya, 1998) (Giaretta and Sawaya 1998; Table 1), from the $B$. didactylus group.

Serra da Palha is situated on the island Ilha de São Francisco, where the sandy soil is particularly young, having an age of approximately 5,000 years (Zular et al. 2013). If a species of the montane groups of Brachycephalus is indeed present at lowland forests in young terrains of a few thousands of years, that would be of great relevance to understanding the evolution of spatial occupation and dispersal of the genus. However, according to the present data, no evidence has emerged indicating the presence of species from the $B$. pernix species group in lowland forest types (Table 1).

\section{Acknowledgements}

We thank Milene Fornari for her help with the literature on the geomorphology of the study region. Claudia Arraes provided valuable assistance in preparing the distribution map. André E. Confetti, Júnior Nadaline, and Cláudia Golec helped with some of the fieldwork. The Fundação Grupo Boticário de Proteção à Natureza helped by covering the field trip costs of some expeditions (through the project A0010_2014). LT was a FAPESP fellow (process 17/21611-9) and now is a CAPES/Reitoria fellow, and MRP is a CNPq fellow (process 301636/2016-8571334/2008-3). ICMBio/SISBIO provided the collection permit. Marcelo Gehara and Vinícius de Avelar São Pedro provided valuable comments that improved our manuscript.

\section{Authors' Contributions}

MRB, LFR, LT, and MRP made field works; MRB, LFR, LT, and MRP collected the data; MRB and LT wrote the text and made the analysis; LFR took the photographs.

\section{References}

Bornschein MR, Firkowski CR, Belmonte-Lopes R, Corrêa L, Ribeiro LF, Morato SAA, Antoniazzi-Jr. RL, Reinert BL, Meyer ALS, Cini FA, Pie MR (2016a) Geographic and altitudinal distribution of Brachycephalus Fitzinger (Anura: Brachycephalidae) endemic to the Brazilian Atlantic Rainforest. PeerJ 4: e2490. https://doi.org/10.7717/peerj.2490

Bornschein MR, Ribeiro LF, Blackburn DC, Stanley EL, Pie MR (2016b) A new species of Brachycephalus (Anura: Brachycephalidae) from Santa Catarina, southern Brazil. PeerJ 4: e2629. https://doi.org/10.7717/peerj.2629

Bornschein MR, Teixeira L, Ribeiro LF (2019) New record of Brachycephalus fuscolineatus Pie, Bornschein, Firkowski, BelmonteLopes \& Ribeiro, 2015 (Anura, Brachycephalidae) from Santa Catarina state, Brazil. Check List 15: 379-385. https://doi.org/10. 15560/15.3.379

Firkowski CR, Bornschein MR, Ribeiro LF, Pie MR (2016) Species delimitation, phylogeny and evolutionary demography of co-dis- 
tributed, montane frogs in the southern Brazilian Atlantic Forest. Molecular Phylogenetics and Evolution 100: 345-360. https://doi. org/10.1016/j.ympev.2016.04.023

Giaretta AA, Sawaya RJ (1998) Second species of Psyllophryne (Anura: Brachycephalidae). Copeia 1998: 985-987. https://doi.org/ $10.2307 / 1447345$

Guimarães CS, Luz S, Rocha PC, Feio RN (2017) The dark side of pumpkin toadlet: a new species of Brachycephalus (Anura: Brachycephalidae) from Serra do Brigadeiro, southeastern Brazil Zootaxa 4258: 327-344. https://doi.org/10.11646/zootaxa.4258.4.2

McCormack JE, Huang H, Knowles LL (2009) Sky islands. In: Gillespie RG, Clague D (Eds), Encyclopedia of islands. University of California Press, Berkeley, 839-843.

Monteiro JPC, Condez TH, Garcia PCA, Comitti EJ, Amaral IB, Haddad CFB (2018) A new species of Brachycephalus (Anura, Brachycephalidae) from the coast of Santa Catarina state, southern Atlantic Forest, Brazil. Zootaxa 4407 (4): 483-505. http://doi. org/10.11646/zootaxa.4407.4

Pie MR, Meyer ALS, Firkowski CR, Ribeiro LF, Bornschein MR (2013) Understanding the mechanisms underlying the distribution of microendemic montane frogs (Brachycephalus spp., Terrarana: Brachycephalidae) in the Brazilian Atlantic Rainforest. Ecological Modelling 250: 165-176. https://doi.org/10.1016/j.ecol model.2012.10.019

Pie MR, Faircloth BC, Ribeiro LF, Bornschein MR, McCormack JE (2018a) Phylogenomics of montane frogs of the Brazilian Atlantic Forest is consistent with isolation in sky islands followed by climatic stability. Biological Journal of the Linnean Society 125 : 72-82. https://doi.org/10.1093/biolinnean/bly093

Pie MR, Ribeiro LF, Confetti AE, Nadaline MJ, Bornschein MR (2018b) A new species of Brachycephalus (Anura: Brachycephalidae) from southern Brazil. PeerJ 6: e5683. https://doi.org/10.7717/ peerj.5683

Ribeiro LF, Bornschein MR, Belmonte-Lopes R, Firkowski CR, Morato SAA, Pie MR (2015) Seven new microendemic species of Brachycephalus (Anura: Brachycephalidae) from southern Brazil. PeerJ 3: e1011. https://doi.org/10.7717/peerj.1011

Ribeiro LF, Blackburn DC, Stanley EL, Pie MR, Bornschein MR (2017) Two new species of the Brachycephalus pernix group (Anura: Brachycephalidae) from the state of Paraná, southern Brazil. PeerJ 5: e3603. https://doi.org/10.7717/peerj.3603

Schwartz CA, Castro MS, Pires Jr. OR, Maciel NM, Schwartz ENF, Sebben A (2007) Princípios Bioativos da Pele de Anfíbios: Panorama Atual e Perspectivas. In: Nascimento LB, Oliveira ME (Eds) Herpetologia no Brasil II. Sociedade Brasileira de Herpetologia, Belo Horizonte, 146-168.

Teixeira L, Ribeiro LF, Corrêa L, Confetti AE, Pie MR, Bornschein MR (2018) A second record of the recently described Brachycephalus albolineatus Bornschein, Ribeiro, Blackburn, Stanley \& Pie, 2016 (Anura: Brachycephalidae). Check List 14: 10131016. https://doi.org/10.15560/14.6.1013

Veloso HP, Rangel-Filho ALR, Lima JCA (1991) Classificação da vegetação brasileira, adaptada a um sistema universal. Instituto Brasileiro de Geografia e Estatística, Rio de Janeiro, 123 pp.

Yeh J (2007) The effect of miniaturized body size on skeletal morphology in frogs. Evolution 56: 628-641. https://doi.org/10.1111/ j.0014-3820.2002.tb01372.x

Zular A, Sawakuchi AO, Guedes CCF, Mendes VR, Nascimento Jr. DR, Giannini PCF, Aguiar VAP, DeWitt R (2013) Late Holocene intensification of colds fronts in southern Brazil as indicated by dune development and provenance changes in the São Francisco do Sul coastal barrier. Marine Geology 335: 64-77. https://doi. org/10.1016/j.margeo.2012.10.006 